\title{
China-Russia Partnership and Competition Impact on Strategic Security in Asia*
}

\author{
WU Fei \\ Jinan University, Guangzhou, China \\ LI Xuan \\ South China Normal University, School of Foreign studies, Guangzhou, China
}

\begin{abstract}
Russia and China are celebrating their "strategic partnership", and have been vastly expanding their cooperation since 2014. Their close alliance is based on economic and geopolitical considerations. While it is mutually beneficial, it also has its limitations. China and Russia mostly agree with each other on structural issues such as redefining the parameters of international governance. However, they also continue to encounter disagreements and conflicts over conjectural issues such as energy and arms trade. We conclude that in the Asia-Pacific, China and Russia will likely develop a more comprehensive relationship that may have greater practical implications for the region's security and stability. China and Russia continue to seek to align their strategies more comprehensively against the backdrop of the evolving geopolitical environment by working to overcome existing disagreements and exploring new areas of cooperation.
\end{abstract}

Keywords: Xi Jinping, Putin, strategic partnership, Competition

After the Chinese leader Xi Jinping paid his first official to Moscow, the Chinese scholars have concluded that China-Russia relationships are the most important and positive relationships than any others. Indeed, the economic and geopolitical ties make these two counties go together more closely since the Union of Soviet Socialist Republics (USSR) collapsed. Now, China is afraid of that the United States will unite Russia to hinder China's rising. So, in Ukraine crisis, China witnessed the confrontation between Russia and USA around the Crimea, it will let the Chinese authority thought of its domestic problems of separatism with Tibet, Xinjiang, and Taiwan. Russia could face the Western economic sanction and back to the cold-war confrontation, but how about China? In this situation, China must need Russia's support to fulfill Xi's reform. The US rebalancing policy is regarded as the most challengeable threat to the China's reform.

\section{China-Russia Strategic Partnership Matters China}

With the escalation of disputed islands in the Asian-Pacific region, China will be the target in the US-China strategic competition. In recent years, Russia has expanded its relationships with the Asian countries;

\footnotetext{
* This article support by National Social Science Fund Project: Research on the Construction of Institutional Discourse Right in Global Governance-An Empirical Study Based on Sino-Russian Media Communication (全球治理中制度性话语权的构建研 究一基于中俄传媒交流的实证研究 16AZD052).

WU Fei, Professor, School of Journalism and Communication, Jinan University, Guangzhou, China.

LI Xuan, Researcher, South China Normal University, School of Foreign studies, Guangzhou, China.
} 
Russia has found its critical role in implementing its Asian policy to face the complicated situation in APR. Now China relies on Russia's supplying the key military technology and materials, so China's military modernization also promotes their bilateral trade. Now China is the biggest trade partnership for Russia, economic ties will let Putin to improve their relationships (國家政策研究基金會, 2014).

The Council for National Security Policy Studies, which belongs to the China Association of Policy, held the 11th Chinese National Security Forum in Beijing on June 25, 2012. The Chinese-Russia strategic partnership is defined by the pro-governmental experts as the new relationships to defeat the US strategic containment and should be observed from not only bilateral relations but also global strategy. The Chinese participants regarded that the US transferring their global policy toward Asia is the most serious challenge for China's national security and development. They thought that the China-Russia strategic partnership is based on the geopolitical interests (Xinhuanet, 2012).

The Chinese Russian expert Feng Yujun said to the Xinhua News Agency that China and Russia shared the similar conception about the international security and international strategy. China and Russia are the permanent members of the UN Security Council. They need to strengthen the military and security collaboration to face the global threats from overthrowing the governments, international terrorism, and criminal organization. He said Xi's visit to Russia is a substantial and clever diplomacy to develop the Chinese soft power as well (Xinhuanet, 2013).

The Chinese Minister of Foreign Affairs Wang Yi said that during Xi's first visit and high-centered public diplomacy has showed the new central collective leadership of the start of diplomatic trip. The first visit to Russia is to focus on the surrounding environment and deepening the strategic relations between these big powers; attending the Brazil, Russia, India, and China (BRIC) summit is to deepening the new relations among the new emerging powers; visiting three African countries is to focus on the establishment in developing countries. China and Russian will transfer their trade model from the pure purchase and sell to the joint manufacturing products in high-tech and aerospace (Xinhua News Agency, 2013).

As I published an article in Hong-Kong Tungkungpao that Russia's entering WTO will challenge China, because China's investment is to focus on the short-term benefits and developing its own consuming market. Joint manufacturing the high-tech and energy product takes too much time to see the benefits. Russia's Far East development is to focus on refreshing the infrastructure and attracting the long-term investment. If Russia can balance the regional relationships in Asia, Russia will become the most important regional actor. The different investment directions between China and Russia increase the degree of mutual cooperation. (Takungpao.com., 2012)

China is facing the dilemma among the Ukrainian crisis. China proclaims the neutral position and appeals to political resolution in order not to offend any parties in this crisis. This made China disappear because China has economic influence in these countries. What does China care is about its attitude toward national sovereignty, based on not intervening others interior issues and maintaining the dignity of national sovereignty. China can only wait and see China's role in the US-Russia conflict around Ukraine crisis is not clear, because Crimea is currently returning from Ukraine to Russia, for China it is difficult to face a referendum on independence within China separatism problem. Therefore, the Sino-Russian strategic partnership did not occur in Ukraine crisis. The ideological differences between Russia and China remain barrier to ally together.

\section{Russia-China Relations: Past and Perspective}

There are still doubt voices about the weakness of the Russian government because the Russian 
government has made too many compromises to China on the boundaries. Besides, Russia does not have the superiority to the Chinese modernized army. However, just like the majority of the Russian sinologist, Alexandra Lukin assumed that China-Russian strategic partnership is beneficial for both countries to have more power in international arena and economic development.

The Russian people met with the Chinese people about 400 years ago. They met at the Far Eastern expansion. Issue of reconciling the boundaries between them demands a lot of time and effort. By the beginning of 20th century, two sides signed several agreements on the border. It was the longest land border in the world. there have never been in large-scale wars four centuries of relations between Russia and China. However, at the same time, the relationships from time to time were complicated and sharpened, which even in 1969 resulted in a bloody armed conflict for occupying the island Damanskii (Gladilin, 2012).

In 1966, during the reign of Mao Zedong in Beijing on the walls appeared slogan: "USSR - our enemy!". In the 1980s, in the period of Deng Xiaoping, there was a popular slogan: "Bringing back our mountains and rivers !". In the 1990s, Beijing continued to demand unilateral weakening of the Russian armed forces in areas adjacent to the Russian-Chinese border. In China, the rising generation is taught and educated that Russia is an "aggressor" and a "national debtor of China" (Gladilin, 2012).

On May 16, 1991, in Moscow, representatives of the USSR and China signed an agreement on the border, which was confirmed in the 1996 agreement between Russia and China. The island Damanskii is confirmed as the Chinese territory. The island Tarabarov (Yinlong), which is located at the confluence of Amur and Ussuri rivers, possessing 174 square kilometers and in the past was allotted the combat aircraft flight path of the 11th Russian Army Air Force in the island Large Ussuri, was confirmed as the Chinese territory in 2005 (Gladilin, 2012).

Another opinion is on the possible military conflict between Russia and China. An article is published online said: Obviously, without getting Russian resources areas, China will be unable to implement its expansion into the rest of the world. Russia has no idea about China's aggression and supplies China Siberian and Far East resources. Therefore, we believe that Russia's relations with China will irreversibly deteriorate in 10 years and can become intolerable. After 10-15 years of military power, China will be comparable with the power of the United States and will exceed the capacity of the Russian armed forces. ${ }^{1}$

Russia newspaper Russiskaya Gazeta published an article "China-Russia: Why do they need each other?" (Lukin, 2013). Russia Sinologist Alexandar Lukin thought that Russia and China are very interested in cooperation in the international arena. China shares Russia's view of the future structure of the world, which is expressed by the notion of "multipolarity". Realistically, this means that both countries would like to see the world, which is not dominated by one power, but several centers on the basis of international law and the UN Charter. Russia-China cooperation is necessary for the development of Siberia and the Far East. China is an important partner of Russia within the framework of Shanghai Cooperation Organization (SCO), where the members country work together to solve the problems of boundary demarcation and fight against the regional extremism and terrorism. Now, $\mathrm{SCO}$ is searching for the more scope of cooperation both in military but also economic aspects.

Lukin also assumed that new topic Russian-Chinese partnership is also regarded as a reaction to the global economic crisis and their desire to reform the international financial system of the governance International

\footnotetext{
1 Война: Китай vs Россия кто победит? (China VS Russia who will win?), video TV program, http://3mv.ru/publ/vojna_kitaj_vs_rossija_kto_pobedit_video/3-1-0-12172.
} 
Monetary Fund (IMF) and the World Bank. Now these two countries are seeking an alternative of the world economic order. One of the most important cooperation is the dynamic group BRICS. Beijing is interested in that Stable Russia is a certain counterbalance for the United States and Western Europe and this is beneficial for China implementing its "independent and autonomous" foreign policy. Stable situation on the border with Russia, as well as other neighbors, is important for China's economic development, which is to implement the main goal of the current leadership of the country.

\section{Discussion}

China-Russia strategic partnership has impact on the escalated islands conflicts in APR. The competition and cooperation among China, Russia, and the United States will be reflected in several areas:

1. The function of SCO will be strengthened both in the economic and military area. SCO plays more and more important role in regional integration and regional security.

2. With the importance of APR, both Russia and the United States turn their diplomacy toward APR. China's rising is challenged. China cannot face two powers Russia and US cooperate against China's rising. With the escalated tension between US and Russia, now Russia and China has consensus to face the US rebalancing policy in APR.

3. Russia's Far East development needs China's cooperation and this makes these two countries increase the influence in Asia-Pacific Economic Cooperation (APEC) to compete with the United States. The economic and military competition among China, Russia and US is explicit.

4. The barrier between China and Russia to ally together is the ideological uncertainty between these two countries. Different approaches to solve problems will be vivid toward disputed issue and deepen their cooperation confidence.

5. Russia and China will cooperate in geopolitical expansion against North Atlantic Treaty Organization (NATO) expansion. Russia is establishing Eurasia to resume the traditional political influence in central Asia and broaden its relations with the Asian countries. The NATO expansion will push them stand together more closely.

\section{Conclusion}

It appears that a number of centripetal factors lead to China-Russia policy convergence and cooperation. These factors mainly involve geopolitics that broad lines of cooperation emerge from intense major power competition as China and Russia engage the United States in Eurasia and the Asia-Pacific. Geopolitically, compatibility, acceptability, and availability of Chinese and Russian relationship for bilateral and facilitate deeper interaction. Due to its central position in global activities within and across national borders, political and economic spheres help two countries' cooperation, which renders it a valuable policy instrument.

In the context of China-Russia relations, catalyzed by viable conjunctures, the strategic importance of geopolitics as a policy tool has grown considerably over the years, helping create a virtuous cycle of greater cooperation in response to internal needs and external challenges. The geopolitical issues nexus, in this case, reflects the centrality of resource diplomacy in the triangulation of domestic, regional and international politics. China and Russia will have an increasingly broader and deeper cooperation and diplomacy will maintain centrality in the frame of SCO BRICS and APEC as a basis to add material substance to the relationship. 


\section{References}

Gladilin, I. (2012). China presented to Russia territorial. Retrieved from http://www.km.ru/world/2012/08/15/pogranichno-vizovye-voprosy-za-rubezhom/kitai-predyavil-rossii-territorialnye-prete

HU, F. Y. \& WU, F. (2013). Russia in Transition: Regional Integration, Media Censorship and Culture Institutes 1st Unabridged Edition, Cambridge Scholars Publishing. (British LibraryCataloguing in Publication Data)

Lukin. A. V. (2013). China and Russia: why are they friendship each other? Retrieved from http://www.rg.ru/2013/04/16/kitai-rossia.html

Takungpao.com. (2012). 吴非:俄罗斯“入世”中国面临巨大挑战 (Wu Fei: Russia join “WTO” China faces huge challenges). Retrieved from http://news.takungpao.com.hk/world/watch/2012-08/995494.html

WU, F. (2007a). The Relationship between Putin's Media Reforms and His Ideological Tendency. Intercultural Communication Studies, XVI(1), USA.

WU, F. (2007b). Media democratization should not be the responsible agent for the Disaggregation of USSR. China Media Research, 3(1), 2007, USA.

WU, F. (2015a). Parade effectively demonstrates China's status to the world. Retrieved from https://www.chinadaily.com.cn/opinion/2015-09/03/content_21785263.htm

WU, F. (2015b). Coordination of Belt and Road strategy and US rebalancing policy. Retrieved fromhttp://www.ydyliit.com/index.php?m=content\&c=index\&a=show\&catid=245\&id=7697

WU, F. (2018). Russiagate: A Double-Edged Sword for US-Russia Relations in the Process of Changing the International Order and Mapping a New Geopolitical World. Journal of Communication and Public Diplomacy, 1(1), September 2018 (Serial Number 1).

Xinhua News Agency. (2013). 王毅谈习近平主席出访并出席金砖国家领导人会晤 (Wang Yi talks about President Xi Jinping's visit and attendance at the BRICS leaders' meeting). Retrieved from http://world.people.com.cn/n/2013/0331/c157278-20977333.html

Xinhuanet. (2012). 从长远战略考虑积极推进中俄关系 (From long-term strategic considerations in China-Russia relations for Actively advance). Retrieved from http://big5.xinhuanet.com/gate/big5/news.xinhuanet.com/world/2012-07/12/c_123406128.htm

Xinhuanet. (2013). 专家解读习近平主席访问俄罗斯成果 (Experts interpret the results of President Xi Jinping's visit to Russia). Retrieved from http://news.xinhuanet.com/world/2013-04/03/c_124537249_2.htm

政策研究基金会 (Policy Research Foundation). (2014). 习普会深化中俄战略合作关系，安全(析) 103-009 号 (Xi and Putin will deepen develop Sino-Russian strategic partnership, Safety analysis No. 103-009). Retrieved from https://www.npf.org.tw/3/13225 